\title{
Chromatin-wide and transcriptome profiling integration uncovers p38a MAPK as a global regulator of skeletal muscle differentiation
}

Jessica Segalés ${ }^{1}$, Abul B. M. M. K. Islam², Roshan Kumar ${ }^{3}$, Qi-Cai Liư ${ }^{4}$, Pedro Sousa-Victor ${ }^{1,7}$, F. Jeffrey Dilworth ${ }^{4}$, Esteban Ballestar ${ }^{5}$, Eusebio Perdiguero ${ }^{1 *}$ and Pura Muñoz-Cánoves ${ }^{1,6^{*}}$

\begin{abstract}
Background: Extracellular stimuli induce gene expression responses through intracellular signaling mediators. The p38 signaling pathway is a paradigm of the mitogen-activated protein kinase (MAPK) family that, although originally identified as stress-response mediator, contributes to establishing stem cell differentiation fates. p38a is central for induction of the differentiation fate of the skeletal muscle stem cells (satellite cells) through not fully characterized mechanisms.

Methods: To investigate the global gene transcription program regulated by p38a during satellite cell differentiation (myogenesis), and to specifically address whether this regulation occurs through direct action of p38a on gene promoters, we performed a combination of microarray gene expression and genome-wide binding analyses. For experimental robustness, two myogenic cellular systems with genetic and chemical loss of p38a function were used: (1) satellite cells derived from mice with muscle-specific deletion of p38a, and (2) the C2C12 murine myoblast cell line cultured in the absence or presence of the p38a/ $\beta$ inhibitor SB203580. Analyses were performed at cell proliferation and early differentiation stages.

Results: We show that p38a binds to a large set of active promoters during the transition of myoblasts from proliferation to differentiation stages. p38a-bound promoters are enriched with binding motifs for several transcription factors, with Sp1, Tcf3/E47, Lef1, FoxO4, MyoD, and NFATc standing out in all experimental conditions. p38a association with chromatin correlates very well with high levels of transcription, in agreement with its classical function as an activator of myogenic differentiation. Interestingly, p38a also associates with genes repressed at the onset of differentiation, thus highlighting the relevance of p38-dependent chromatin regulation for transcriptional activation and repression during myogenesis.
\end{abstract}

Conclusions: These results uncover p38a association and function on chromatin at novel classes of target genes during skeletal muscle cell differentiation. This is consistent with this MAPK isoform being a transcriptional regulator.

\footnotetext{
*Correspondence: eusebio.perdiguero@upf.edu; pura.munoz@upf.edu 'Department of Experimental and Health Sciences, Pompeu Fabra University (UPF), CIBER on Neurodegenerative diseases (CIBERNED), Barcelona, Spain Full list of author information is available at the end of the article
} 


\section{Background}

Cellular signaling is essential for the cells' ability to respond to the environment by integrating external cues to intracellular mediators and effectors. Activation of mitogen-activated protein kinases (MAPKs) constitutes a paradigm of intracellular signaling. p38, a subgroup of the MAPKs, was initially identified as a transducer of the response to inflammatory and environmental stress conditions. There are four p38 MAPKs in mammals: MAPK14 (p38 ${ }_{\alpha}$ ), MAPK11 (p38 $\left.8_{\beta}\right)$ MAPK12 (p38 ${ }_{\gamma}$ ), and MAPK13 $\left(\mathrm{p} 38_{\delta}\right)[1,2]$. Activation of these MAPKs has also been associated with the differentiation capacity of several stem cell types. In particular, p38 plays an integral role in the fate decision of stem cells of the skeletal muscle lineage $[3,4]$. Muscle stem cells (also called satellite cells), established early during development, are marked by the expression of the paired-box transcription factor Pax7, and have as principal mission sustaining skeletal muscle regeneration $[5,6]$. When stimulated by an injury or disease, these normally quiescent stem cells are activated, begin to proliferate as myoblasts and, subsequently, they either exit the cell cycle, differentiate and fuse to form new fibers (or repair damaged ones), or self-renew to replenish the satellite cell pool. In vitro studies using cellular models (satellite cell-derived primary myoblasts or myoblast cell lines) that recapitulate the myogenic stages of the in vivo regeneration process, in combination with the chemical inhibitor of $p 38 \alpha /$ p38 $\beta$ SB203580, have shown an active participation of the p38 MAPK pathway in each stage, with a principal function as a regulator of the myoblast proliferation-todifferentiation transition, by inducing cell cycle withdrawal and expression of muscle differentiation-specific genes [3, 4, 7-9].

Consistent with their kinase activity, several transcription factors can be directly phosphorylated by $\mathrm{p} 38 \alpha / \beta$ MAPKs, including E47, the dimerization partner of the master myogenic regulatory factors (MRFs) of the MyoD family, and MEF2, a transcription factor cooperating with the MRFs in myogenic gene transcription; these phosphorylation events have a profound effect on gene expression as they modulate the activity of MyoD-E47 and MEF2 on muscle-specific promoters [3, 10-14]. Furthermore, by phosphorylating the chromatin-associated protein BAF60c, p38 $\alpha / \beta$ kinases contribute to the assembly of the myogenic transcriptosome on the chromatin of muscle loci by promoting the recruitment of SWI/SNF chromatin remodeling complex [15-17] and ASH2Lcontaining mixed-lineage leukemia (MLL) methyltransferase complex $[18,19]$. Through phosphorylation, $\mathrm{p} 38 \alpha$ also recruits SNF2-related CBP activator protein (SRCAP) subunit $\mathrm{p} 18^{\text {Hamlet }}$ to muscle loci, which is in turn required for H2A.Z accumulation and transcriptional activation [20]. p38 $\alpha$-mediated phosphorylation of Ezh2, the enzymatic subunit of polycomb repressor complex 2 (PRC2) also regulates the expression of Pax7, thus controlling the decision of satellite cells to proliferate or differentiate [21]. By contrast, p38y represses MyoD transcriptional activity by direct phosphorylation, via association with the H3K9 methyltransferase KMT1A, thereby also influencing this myogenic decision [22]. Thus, the p38 MAPK pathway can either activate or repress gene expression in satellite cells, depending on the engagement of specific p38 isoforms. Notably, in vitro studies using satellite cells lacking individual p38 family members showed that the four p38 isoforms are not completely redundant during myogenesis $[7,23,24]$, and uncovered a predominant role of the p $38 \alpha$ isoform in myogenic differentiation [7, 23, 24], with p38y signaling contributing to proliferation by preventing premature differentiation [22], whereas p38 $\beta$ and p38 $\delta$ appeared rather dispensable for these processes [7, 23]. Because muscle regeneration in vivo can proceed quite effectively in the absence of the p38y isoform [23], but is defective in the absence of $p 38 \alpha$ [25], p38 $\alpha$ is indeed acknowledged as the master kinase for reprogramming gene expression during the proliferation-to-differentiation switch of satellite cells in vitro and in vivo.

Studies in yeast have shown that the p38 MAPK homolog, Hog1, activates transcription in response to osmotic stress by acting directly at chromatin [26, 27]. Likewise, mammalian p38 MAPK can bind to some stress-responsive loci upon exposure to several types of stresses, emphasizing that the association of the MAPK with target promoters can stimulate gene expression [28]. In skeletal myoblasts, p38 $\alpha$ has also been found to bind certain muscle-specific genes such as myogenin, muscle creatine kinase, and myosin heavy chain during the process of myogenic differentiation $[15,21]$. However, whether $\mathrm{p} 38 \alpha$ can regulate gene transcription globally during myogenesis via direct action on gene promoters is unknown. Here, we assessed the genomewide enrichment of the p38 $\alpha$ MAPK isoform, coupled to the p38 $\alpha$-dependent global gene expression program, during the switch of myogenic cells from proliferationto-differentiation stages. Our findings enlarge the picture of p38 $\alpha$ MAPK as an important coordinator of myogenic gene expression through direct association to chromatin.

\section{Methods \\ Cell culture}

The $\mathrm{C} 2 \mathrm{C} 12$ myoblast cell line was cultured at $37{ }^{\circ} \mathrm{C}$ in $5 \% \mathrm{CO} 2$ in Dulbecco's Modified Eagle's Medium (DMEM; Invitrogen) with $10 \%$ fetal bovine serum (FBS) and supplemented with antibiotics $(100 \mathrm{U} / \mathrm{ml}$ penicillin and $100 \mu \mathrm{g} / \mathrm{ml}$ streptomycin (growth medium (GM)).

Satellite cells were obtained from p38 $\alpha$-deficient and WT mouse muscles, as described in [7] and their 
myoblast progeny was maintained on collagen-coated dishes in Ham's F10 medium supplemented with $20 \%$ FBS, $100 \mathrm{U} / \mathrm{ml}$ penicillin, $100 \mu \mathrm{g} / \mathrm{ml}$ streptomycin, and $5 \mathrm{ng} / \mathrm{ml}$ bFGF (GM). These cells are referred to as satellite cells throughout the study. Experiments were performed by plating cells on Matrigel $^{\text {Tix }}$ (BD Biosciences) Basement Membrane Matrix-coated dishes. To induce differentiation in both primary and $\mathrm{C} 2 \mathrm{C} 12$ myoblasts, GM was replaced by differentiation medium (DM) (DMEM supplemented with $2 \%$ horse serum, $2 \mathrm{mM} \mathrm{L-}$ glutamine, $100 \mathrm{U} / \mathrm{ml}$ penicillin, and $100 \mu \mathrm{g} / \mathrm{ml}$ streptomycin) at myoblast subconfluence. For p38 $\alpha / \beta$ MAPK inhibition studies, SB203580 was added directly to DM at a final concentration of $5 \mu \mathrm{M}$.

\section{Western blotting}

Western blotting was performed as described previously [7]. Antibodies used were phospho-p38 (Thr180/Tyr182) (Cell Signaling 9211) and Tubulin (Sigma T-6199).

\section{Immunofluorescence in $\mathrm{C} 2 \mathrm{C} 12$ myoblasts}

$\mathrm{C} 2 \mathrm{C} 12$ cells were fixed in PFA $4 \%$ for $10 \mathrm{~min}$ at room temperature, washed with PBS, and permeabilized with $0.5 \%$ Triton X-100 in PBS during 10 min. Cells were incubated with blocking solution (10 \% goat serum, $10 \%$ BSA in PBS) for $1 \mathrm{~h}$ at room temperature and then overnight at $4{ }^{\circ} \mathrm{C}$ with p38 $\alpha$ antibody (Santa Cruz Biotechnology sc-535) diluted 1/50 in blocking solution. After three washes in PBS-Tween $0.025 \%$, cells were further incubated with goat anti-rabbit conjugated with AlexaFluor 488 (Invitrogen; 1/250) for $1 \mathrm{~h}$. DAPI (1/1000) was used to label DNA, and the slides were mounted with Mowiol. Imaging was carried out with TCS-SPE confocal microscope (Leica) using LAS AF software.

\section{RNA isolation, reverse transcription (RT), and quantitative PCR (qPCR)}

Total RNA from proliferating and differentiating myoblasts was isolated with TriPure Isolation Reagent and quantified with Nanodrop. M-MLV reverse transcriptase (Promega) was used to synthesize cDNAs from the total RNA $(1 \mu \mathrm{g})$ following the manufacturer's recommendations. RT-qPCR reactions were performed with SYBR Green in 384-well plates using the Roche LC-480 cycler (Roche Applied Science). The mRNA expression of target genes was normalized to L7 expression, and the data are represented as the mean \pm SD of three independent experiments. Primer sequences are listed in Additional file 1: Table S2.

\section{Chromatin immunoprecipitation (ChIP) assay}

ChIP assays were performed from approximately $5^{*} 10^{6}$ $\mathrm{C} 2 \mathrm{C} 12$ cells per experiment. Briefly, cells were cross- linked with $1 \%$ formaldehyde for $10 \mathrm{~min}$ at room temperature, and the crosslinking was then quenched with $0.125 \mathrm{M}$ glycine for $5 \mathrm{~min}$. Cross-linked cells were washed twice with cold PBS, resuspended in $600 \mu \mathrm{l}$ of SDS lysis buffer (1 \% SDS, $10 \mathrm{mM}$ EDTA, $50 \mathrm{mM}$ Tris$\mathrm{HCl}, \mathrm{pH}$ 8.1, plus protease inhibitors) and incubated on ice for $10 \mathrm{~min}$. Cell lysate was sonicated to shear chromatin to an average length of 200-500 bp using a Diagenode Bioruptor. Sonicated samples were centrifuged at 13,000 rpm for $10 \mathrm{~min}$ and the chromatin concentration of the supernatant was quantified. Seventy microgram of chromatin were diluted 10-fold in ChIP dilution buffer (0.01 \% SDS, $1.1 \%$ Triton X-100, 1.2 mM EDTA, $167 \mathrm{mM} \mathrm{NaCl}, 16.7 \mathrm{mM}$ Tris- $\mathrm{HCl}, \mathrm{pH}$ 8.1, plus protease inhibitors) and immunoprecipitated overnight at $4{ }^{\circ} \mathrm{C}$ with $3 \mu \mathrm{g}$ of p38 $\alpha$ antibody (Cell Signaling 9218) and $1 \mu \mathrm{g}$ of MyoD and Mef2 antibodies (Santa Cruz Biotechnology sc-304 and sc-13917, respectively) or control IgG antibody (Cell Signaling 2729). Twenty microliter of Magna ChIP Protein A + G Magnetic Beads (Millipore) were added and incubated for $1 \mathrm{~h}$ at $4{ }^{\circ} \mathrm{C}$. Beads were successively washed with $1 \mathrm{ml}$ of different buffers: lowsalt immune complex wash buffer $(0.1 \%$ SDS, $1 \%$ Triton $\mathrm{X}-100,2 \mathrm{mM}$ EDTA, $20 \mathrm{mM}$ Tris- $\mathrm{HCl}, \mathrm{pH} 8.1$, $150 \mathrm{mM} \mathrm{NaCl}$ ), high-salt immune complex wash buffer (0.1 \% SDS, 1 \% Triton X-100, 2 mM EDTA, $20 \mathrm{mM}$ Tris- $\mathrm{HCl}, \mathrm{pH}$ 8.1, $500 \mathrm{mM} \mathrm{NaCl}$ ), $\mathrm{LiCl}$ immune complex wash buffer $(0.25 \mathrm{M} \mathrm{LiCl}, 1 \% \mathrm{NP} 40,1 \%$ deoxycholate, $1 \mathrm{mM}$ EDTA, $10 \mathrm{mM}$ Tris- $\mathrm{HCl}, \mathrm{pH} 8.1)$, and TE (1 mM EDTA, $10 \mathrm{mM}$ Tris- $\mathrm{HCl}, \mathrm{pH} 8.0$ ). To elute the immunocomplexes, beads were incubated twice in elution buffer (1 \% SDS, $100 \mathrm{mM} \mathrm{NaHCO3)} \mathrm{for} 15 \mathrm{~min}$ at room temperature. The crosslinking was reverted by further incubating the DNA at $65{ }^{\circ} \mathrm{C}$ overnight. DNA was extracted with phenol/chloroform, ethanol-precipitated and resuspended in $80 \mu \mathrm{l}$ of $\mathrm{H}_{2} \mathrm{O}$ for further analysis. Bound fraction and input were analyzed by PCR and qPCR using specific primer sets for each of the analyzed promoters (see Additional file 1: Table S2). Relative recruitment is calculated as the amount of amplified DNA normalized to input and relative to values from control IgG immunoprecipitation, which were set as 1 in each calculation.

\section{Microarray analysis}

RNA samples were collected from $\mathrm{C} 2 \mathrm{C} 12$ cells (proliferating and differentiated for $24 \mathrm{~h} \pm$ the $\mathrm{p} 38 \alpha / \beta$ inhibitor SB203580) and primary myoblasts from WT and p38 $\alpha$ deficient mice in proliferation conditions and at $24 \mathrm{~h}$ of differentiation. Transcriptome analysis was performed using the 44K Whole-Mouse Genome (Agilent), and the RNA labeling and hybridization process was performed following the manufacturer's instructions. Microarray analysis was performed with three samples per condition; for 
the primary myoblasts, each sample was a pool of three independent cultures. Moreover, and to avoid bias labeling artifacts, dye swap experiments were performed. Fluorescent images were obtained with an Agilent G2565BA scanner. Microarray images were quantified using GenePix software. Only spots with signal intensities twice above the local background, not saturated, and not flagged by GenePix were considered reliable and used for subsequent analysis. Extracted intensities were subtracted from the local background, and the $\log 2$ ratios were normalized in an intensity-dependent fashion by global LOWESS. For normalization and differential expression analysis, we used Bioconductor [29] (www.bioconductor.org) package LIMMA [27] for Agilent two-color microarray data. For differential expression analysis, we filtered for genes that show at least Log2FC $0.25(\geq+0.25$ for upregulation and $\leq-0.25$ for downregulation).

\section{ChIP-on-chip analysis}

Chromatin immunoprecipitation was performed in quadruplicate from independent $\mathrm{C} 2 \mathrm{C} 12$ cultures of each condition. Each sample was cross-linked, and immunoprecipitation was performed as described above using p $38 \alpha$-specific antibodies (Cell Signaling). To avoid the high variability detected with $\mathrm{p} 38 \alpha$ antibody, immunoprecipitated and input DNA were pooled, labeled by ligation-mediated PCR with $\mathrm{Cy} 5$ and $\mathrm{Cy} 3$ fluorescent dyes, respectively. Pools of labeled DNA were hybridized to a $244 \mathrm{~K}$ Mouse Promoter Chip (Agilent) following the manufacturer's instructions. The array was scanned and analyzed with GenePix software as explained above. Genome-wide location data were normalized, and the ratio of immunoprecipitated to input DNA was determined for each probe. For each array, a confidence value ( $P$ value) was calculated for each probe using an error model as explained before [27]. Briefly, probes that scored significantly above background were then combined into probe sets of three probes if they passed the following filter: the center probe in the probe set has a single point $P$ value $<0.001$, one of the flanking probes has a single point $P$ value $<0.01$, and the three probes combined have a $P$ value $<0.001$. For binding peaks that typically span over transcribed regions and thus span over several probes, the following filter was used: the center probe in the probe set has a single point $P$ value $<0.005$, the three probes combined have a $P$ value $<0.0001$ and one of the flanking probes has a combined $P$ value $<0.001$. Bound probe sets that overlapped were collapsed into bound regions. For each bound region, the closest ORF was then assigned and the maximum ChIP enrichment identified (see Additional file 2: Table S1).

\section{Bioinformatic and statistical analysis}

Gene ontology analysis was performed using DAVID functional annotation clustering [30]. Gene set enrichment analysis (GSEA) was performed using the default parameters [31]. Venn diagrams were generated using The BEG Ugent tool (http://bioinformatics.psb.ugent.be/webtools/ Venn/). Volcano plots of gene expression and statistical analysis data were performed using Graphpad Prism software. Quantitative data displayed as histograms are expressed as means \pm standard error of the mean (represented as error bars). Results from each group were averaged and used to calculate descriptive statistics. Mann-Whitney $U$ test (independent samples) was used for pairwise comparisons among groups at each time point. Statistical significance was set at a $P$ value $<0.05$.

\section{Mice}

Mice carrying the floxed p38 $\alpha$, allele were generated by Boehringer Ingelheim Pharmaceuticals Inc. (Ridgefield, USA). Floxed p38 $\alpha$ mice were crossed to More-CRE knock-in mice to obtain p38 $\alpha$ knockout mice. All animal experiments and isolation of satellite cells from wild type and knockout mice [7] were approved by the ethics committee of the Barcelona Biomedical Research Park (PRBB) and by the Catalan Government and used sex-, age- and weight matched littermate animals.

\section{Results}

Consequences of genetic and chemical p38a inhibition on the gene expression program of differentiating myoblasts Because p $38 \alpha$ controls the transition of myoblasts from proliferating to differentiating stages, we aimed to study specifically the changes in gene expression occurring during this transition (Fig. 1a). To increase the robustness of the experimental strategy, we used distinct myogenic cellular models and p38 $\alpha$-inhibiting alternatives: satellite cells obtained from muscle of wild type (WT) mice or mice with deletion in p38 [7], and the C2C12 myoblast cell line, cultured in the absence or presence of the $\mathrm{p} 38 \alpha / \beta$ inhibitor SB203580 (SB) (Fig. 1a). Because the $\mathrm{p} 38 \beta$ isoform is not (or lowly) expressed in $\mathrm{C} 2 \mathrm{C} 12$ myoblasts (Additional file 3: Figure S1), the inhibitory action of SB203580 on these cells will likely be attributable to $\mathrm{p} 38 \alpha$. Genome-wide microarrays of both types of cells (with/without genomic or chemical p38 $\alpha$-inhibitory conditions) in proliferation (growth medium (GM)) and early differentiation (24 h in differentiation medium (DM)) states were performed.

Through these analyses, we identified a large number of genes regulated by $\mathrm{p} 38 \alpha$ (Fig. 1b; Additional file 2: Table S1), being this regulation particularly marked at the early $24 \mathrm{~h}$ myoblast differentiation stage. Gene ontology (GO) analysis using DAVID functional annotation clustering of the GO terms showed a downregulation in expression of muscle-differentiation-specific genes for satellite cells lacking p38 $\alpha$, whereas genes involved in proliferation and cell-cycle progression were upregulated 


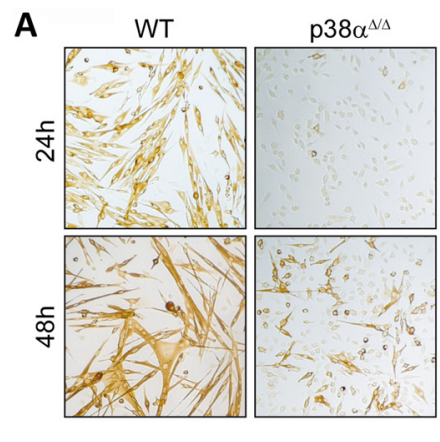

B
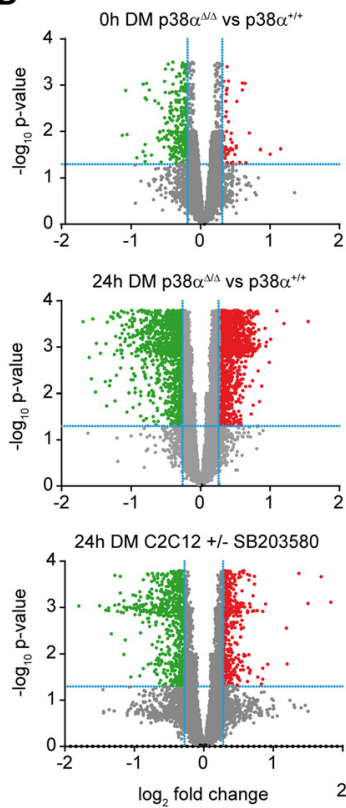

E

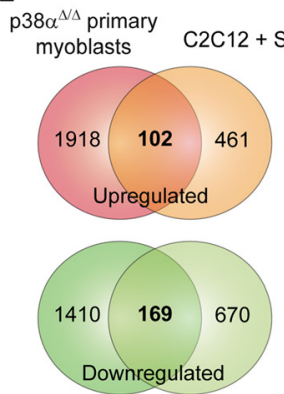

C

D

F
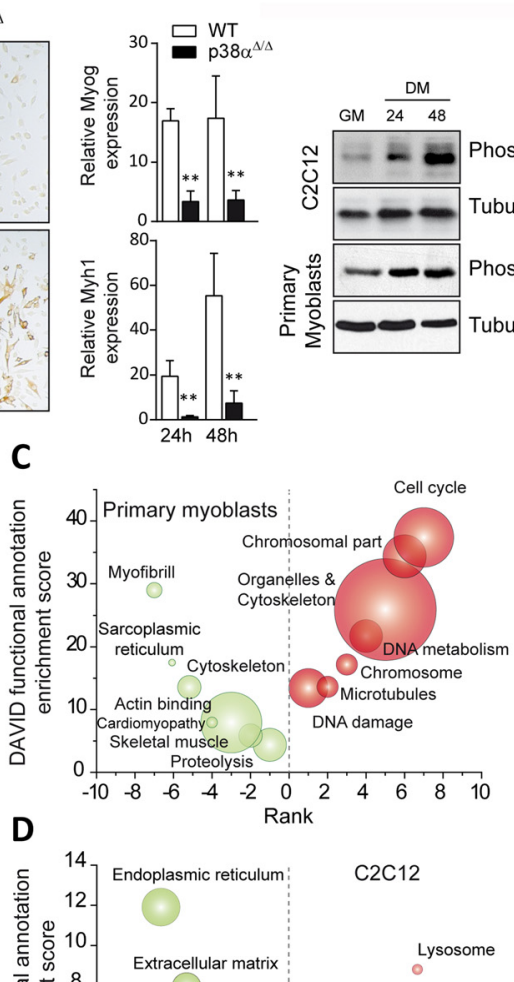

Lysosome
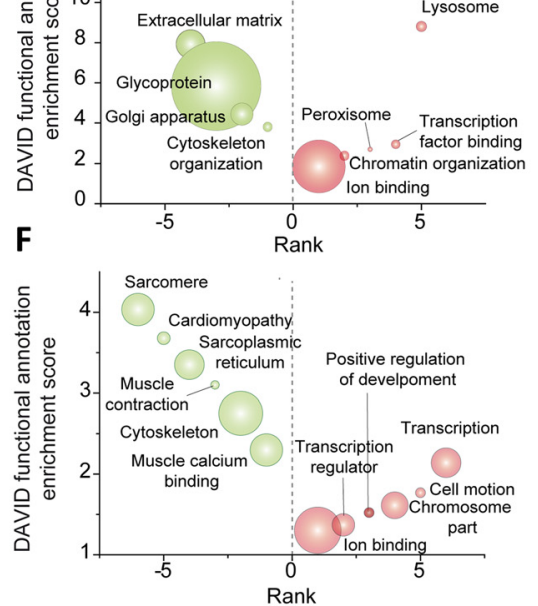

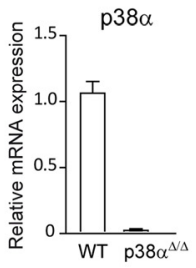

G

$$
\text { Downregulated genes }
$$

H

$$
\text { 48h DM }
$$

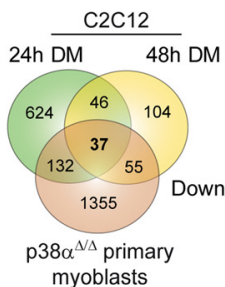

Fig. 1 (See legend on next page.) 


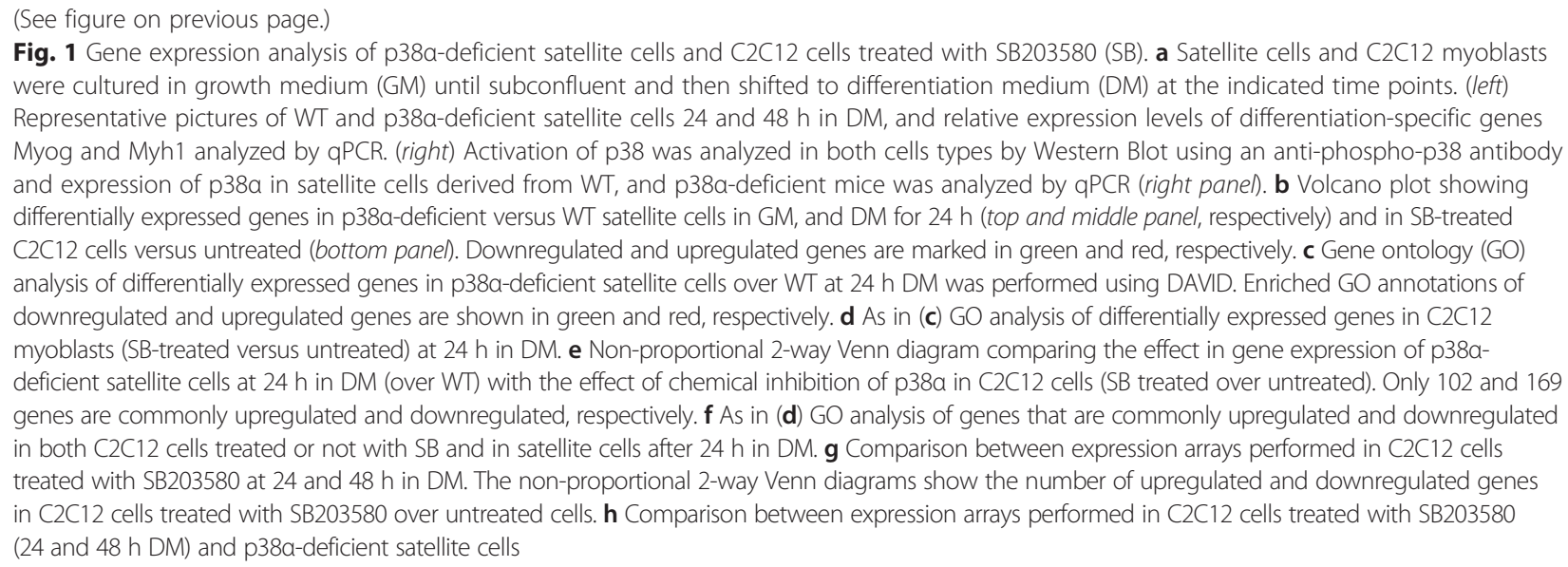

(Fig. 1c). p38 $\alpha$ signaling in satellite cells also appeared to regulate multiple genes and transcription factors that had not been previously related to myogenesis, for example, genes encoding signaling proteins and genes involved in proteolysis or DNA metabolism and damage. In contrast, SB treatment of $\mathrm{C} 2 \mathrm{C} 12$ cells caused downregulation of genes related to secretory pathways and cytoskeleton organization, whereas the expression of genes related to transcription, chromatin organization, or ion binding was upregulated (Fig. 1d). Of note, the cellcycle-related genes that were found upregulated in p38 $\alpha$-deficient satellite cells after $24 \mathrm{~h}$ in DM remained unchanged in SB-treated $\mathrm{C} 2 \mathrm{C} 12$ cells at the same time point; however, SB-treated $\mathrm{C} 2 \mathrm{C} 12$ cells showed upregulation of these proliferationrelated genes at a later time point in DM (i.e., $48 \mathrm{~h}$ ), according to the recently published data [8], suggesting a delay in the cell-cycle exit of $\mathrm{C} 2 \mathrm{C} 12$ immortalized myoblasts, compared to primary satellite cells, in differentiation-promoting conditions. Of the p38 $\alpha$ regulated genes in both experimental conditions, only 102 and 169 genes were commonly up- and downregulated, respectively, in SB-treated $\mathrm{C} 2 \mathrm{C} 12$ myoblasts and p38 $\alpha$-deficient satellite cells (Fig. 1e). Thus, the stringency imposed by the use of distinct muscle cell models and p38-inhibiting strategies allowed the identification of a robust list of bona fide genes dependent on $\mathrm{p} 38 \alpha$ at the onset of myogenic differentiation (Additional file 2: Table S1). GO analysis of genes commonly regulated in SB-treated C2C12 cells, and p38 $\alpha$-deficient satellite cells at $24 \mathrm{~h}$ DM showed that the expression of muscle differentiation-specific genes is commonly downregulated in both types of cells in the absence of p38 $\alpha$ signaling (Fig. 1f). In contrast, genes commonly upregulated in both conditions were related to the transcription and cell motion processes (Fig. 1f).
A further comparison of the expression arrays from $\mathrm{C} 2 \mathrm{C} 12$ myoblasts in DM for 24 and $48 \mathrm{~h}$ (in the absence or presence of $\mathrm{SB}$ ) revealed a dramatic difference in both time points: only $20 \%$ of the genes upregulated by the $48 \mathrm{~h} \mathrm{DM}+\mathrm{SB}$ treatment were also upregulated at the earlier DM + SB $24 \mathrm{~h}$ time point (Fig. 1g); likewise, only $30 \%$ of the downregulated genes at the $48 \mathrm{~h} \mathrm{DM}+\mathrm{SB}$ treatment were common with the $24 \mathrm{~h} \mathrm{DM}+\mathrm{SB}$ conditions. Thus, $\mathrm{p} 38 \alpha$ regulates the muscle differentiation gene program in $\mathrm{C} 2 \mathrm{C} 12$ myoblasts with distinct kinetics (i.e., p38 $\alpha$-dependent early and late myogenic genes) (Fig. 1g). Interestingly, comparison of the 24 and $48 \mathrm{~h}$ $\mathrm{DM}+\mathrm{SB} \mathrm{C} 2 \mathrm{C} 12$ cells with the $24 \mathrm{~h}$ DM p38 $\alpha$-deficient satellite cells demonstrated that, in addition to cell-cycle exit, the kinetics of the p38 $\alpha$-dependent proliferation-todifferentiation gene expression transition program differ between both cell types; indeed, this transition was faster in satellite cells, as shown by the similar number of common p38 $\alpha$-regulated genes in the 24 h-DM satellite-cell time point and in $\mathrm{C} 2 \mathrm{C} 12$ cells at both time points (Fig. 1h). It is probable that the faster differentiation kinetics might be related to the more rapid and pronounced activation of p38 MAPK signaling in satellite cells than $\mathrm{C} 2 \mathrm{C} 12$ cells in the GM to DM transit conditions (Fig. 1a).

We next performed qPCR analysis of p38 $\alpha$-deficient and WT satellite cells (Fig. 2a) and $\mathrm{C} 2 \mathrm{C} 12$ myoblaststreated or not with SB-treated (Fig. 2b) to validate the gene expression microarray results. We confirmed that transcripts belonging to different gene networks are regulated by p38 $\alpha$ (in both genetic and chemical inhibitory settings), including muscle-specific and cellcycle-regulatory genes, multiple transcription factors, and genes encoding signaling proteins.

In order to identify transcription factor binding sites of genes regulated by p38 $\alpha$, we performed a gene set enrichment analysis (GSEA) in both types of cells and p38 $\alpha$-inhibitory conditions. The analysis showed that 

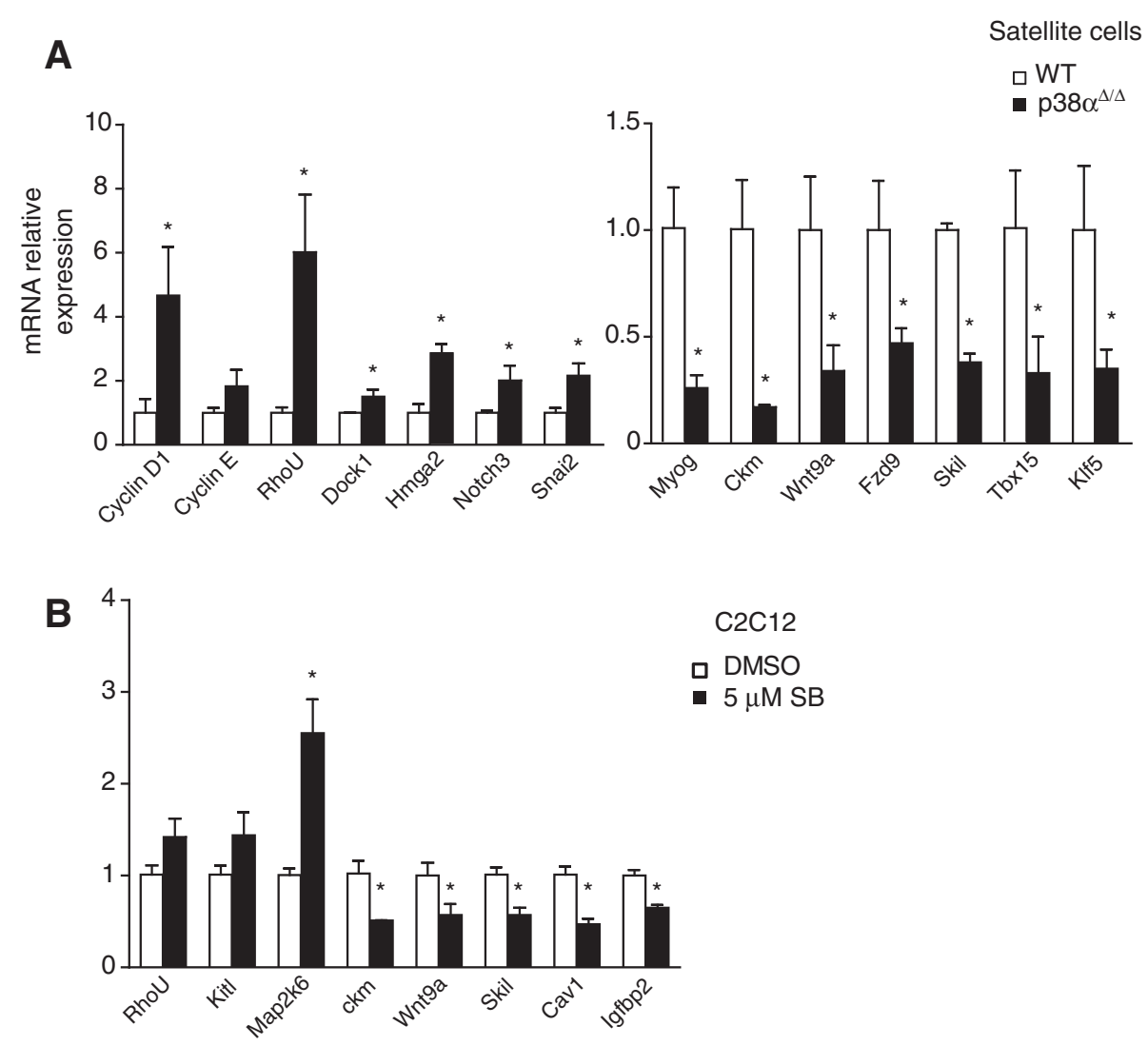

Fig. 2 Validation of the p38a-dependent genes from expression arrays. a p38a-regulated genes were validated by qPCR in satellite cells derived from WT and p38a-deficient mouse muscles after $24 \mathrm{~h}$ in DM. $\mathbf{b}$ Genes regulated by chemical inhibition of p38a were validated by qPCR in differentiating C2C12 myoblasts (24 h DM) treated or not with SB. Different gene networks are regulated by p38a: muscle-specific and cell-cycle regulator genes, transcription factors, and genes encoding signaling proteins. Values are mean \pm SEM of three independent experiments. Non-parametric Mann-Whitney $U$ test was used for comparisons ( $P$ values $<0.05$ )

genes regulated by $\mathrm{p} 38 \alpha$ have enriched binding sites for different transcription factors, such as Sp1, Lef1, Tcf3/ E47, FoxO4, Pax4, MyoD, or NFATc (Fig. 3), and most of them are common in all conditions analyzed (satellite cells $24 \mathrm{~h}$ DM, C2C12 $24 \mathrm{~h}$ DM, and $48 \mathrm{~h}$ DM; upand downregulated). Interestingly, E2F-binding sites are enriched exclusively in p38 $\alpha$-regulated genes in p38 $\alpha$-deficient satellite cells at $24 \mathrm{~h} \mathrm{DM}$, and in C2C12 cells at $48 \mathrm{~h}$ (but not at $24 \mathrm{~h}$ ) DM, consistent with the dysregulation of the cell-cycle/proliferation gene program.

\section{Identification of p38a-chromatin binding sites at the myogenic proliferation-to-differentiation switch}

To investigate whether $\mathrm{p} 38 \alpha$ regulates global gene transcription at the myoblast proliferation-to-differentiation transition by directly acting at chromatin, we investigated the association of $\mathrm{p} 38 \alpha$ to gene promoters in proliferating (GM) and early differentiating myoblasts (24 h DM) by ChIP-on-chip analysis using a p38 $\alpha$-specific antibody. Following our transcriptome analysis, and to focus on the early events of differentiation and p38 $\alpha$ activation, we performed our analysis in $\mathrm{C} 2 \mathrm{C} 12$ cells. The obtained ChIPon-chip data revealed that the binding of p38 $\alpha$ is markedly enriched at many gene promoters both in proliferation and early differentiation stages, consistent with its localization in the nuclear compartment in these two conditions (Additional file 3: Figure S2). A stringent analysis unveiled 2268 p38 $\alpha$-bound genes in myoblasts in GM and 1434-bound genes in DM. We detected a high overlap between GM and $\mathrm{DM}$ as more than 1000 genes were bound by $\mathrm{p} 38 \alpha$ in both myogenic conditions (Fig. 4a). A general clustering analysis of genes bound by p38 $\alpha$ in $\mathrm{C} 2 \mathrm{C} 12$ cells identified genes that could be grouped in five clusters according to the pattern of binding along the promoter (Fig. 4b). Interestingly, cluster 1 included many transcription factors, developmental regulators, and muscle-related genes, whereas cluster 5 was enriched in protein transport, phosphorylation, and cell cycle-related genes. GO analysis revealed common p38 $\alpha$ bound genes enriched in positive and negative regulators of transcription, Wnt signaling pathway, actin cytoskeleton 
Enriched transcription factor binding sites

\begin{tabular}{|c|c|c|c|c|c|c|c|c|}
\hline \multicolumn{3}{|c|}{ Up Primaries 24h } & \multicolumn{3}{|c|}{ Up C2C12 24h + SB } & \multicolumn{3}{|c|}{ Up C2C12 48h + SB } \\
\hline Factor & Genes & $p$-value & Factor & Genes & p-value & Factor & Genes & $p$-value \\
\hline Sp1 & 338 & $5.32 \mathrm{E}-88$ & $\overline{S p 1}$ & 104 & $1.46 \mathrm{E}-28$ & E2f (10) & 15 & $5.81 \mathrm{E}-13$ \\
\hline Lef1 (2) & 264 & $8.29 \mathrm{E}-82$ & Lef1 (2) & 75 & $2.74 \mathrm{E}-22$ & E2f (Tfbp 1$)$ & 14 & 1.33E-11 \\
\hline Tcf3 (E12) & 258 & 4.42E-57 & Foxo4 & 73 & $5.87 \mathrm{E}-20$ & Lef1 (2) & 27 & $9.20 \mathrm{E}-11$ \\
\hline Foxo4 & 230 & 3.99E-56 & Tcf3 (E12) (2) & 81 & $6.16 \mathrm{E}-20$ & E2f4 & 12 & $2.29 \mathrm{E}-09$ \\
\hline Maz:Myc & 236 & $5.79 E-52$ & Srebf1 & 31 & $7.92 \mathrm{E}-16$ & Sp1 & 38 & $3.61 \mathrm{E}-08$ \\
\hline Nfatc & 206 & $3.01 \mathrm{E}-48$ & Nfatc & 62 & 2.03E-15 & Tcf3 (E12) & 34 & $5.51 \mathrm{E}-08$ \\
\hline Myc (2) & 140 & $1.99 \mathrm{E}-43$ & Pax4 & 47 & $1.68 \mathrm{E}-13$ & Pax4 & 22 & $4.59 \mathrm{E}-07$ \\
\hline E2f (13) & 65 & $6.89 \mathrm{E}-40$ & Ap4 & 51 & 3.29E-13 & Maz:Myc & 30 & $7.78 \mathrm{E}-07$ \\
\hline E2f (Tfbp1) & 64 & $1.8 \mathrm{E}-38$ & Maz:Myc & 64 & $6.17 \mathrm{E}-13$ & Nfil3 & 10 & $8.32 \mathrm{E}-07$ \\
\hline E2f (Tfbp2) & 64 & $1.8 \mathrm{E}-38$ & Foxf2 & 37 & 3.82E-12 & Sox9 & 11 & $1.75 \mathrm{E}-06$ \\
\hline Pax4 & 136 & $2.55 \mathrm{E}-30$ & Myod & 37 & 4.47E-12 & Nfatc & 26 & $2.26 \mathrm{E}-06$ \\
\hline Foxf2 & 107 & $1.27 \mathrm{E}-27$ & Tcf8 & 33 & 2.37E-11 & Atf2 & 8 & 3.07E-06 \\
\hline Ets2 & 115 & $4.64 \mathrm{E}-26$ & Myc & 38 & $2.66 \mathrm{E}-11$ & Pou2f1 & 9 & $8.84 \mathrm{E}-06$ \\
\hline Foxa1 & 90 & $8.16 \mathrm{E}-25$ & Ets2 & 38 & $1.11 \mathrm{E}-10$ & Foxo4 & 26 & $9.92 \mathrm{E}-06$ \\
\hline Ddit3 (Chop) & 50 & 1.03E-24 & Atf3 & 25 & $7.25 \mathrm{E}-10$ & Foxf2 & 16 & $1.34 \mathrm{E}-05$ \\
\hline Ap4 & 134 & 1.47E-22 & Zfp161 & 17 & $7.56 \mathrm{E}-10$ & Ets2 & 17 & $2.75 \mathrm{E}-05$ \\
\hline Sox9 & 59 & $1.1 \mathrm{E}-21$ & Foxa1 & 29 & $1.50 \mathrm{E}-09$ & Gata1 & 8 & $3.00 \mathrm{E}-05$ \\
\hline Ap1 & 107 & $8.36 \mathrm{E}-21$ & E4f1 & 27 & 2.22E-09 & Cdc5 & 8 & $4.09 \mathrm{E}-05$ \\
\hline CEBPa & 50 & $1.03 \mathrm{E}-24$ & Ipf1 & 17 & 2.72E-09 & Pax2 & 8 & $4.32 \mathrm{E}-05$ \\
\hline MyoD & 94 & 2.93E-20 & Runx1 & 17 & $2.88 \mathrm{E}-09$ & Pcbp1 & 8 & 4.57E-05 \\
\hline p53 & 43 & $1.01 \mathrm{E}-17$ & Creb1 & 17 & 4.29E-09 & Ipf1 & 8 & 4.57E-05 \\
\hline
\end{tabular}

\begin{tabular}{|c|c|c|c|c|c|c|c|c|}
\hline \multicolumn{3}{|c|}{ Down Primaries 24h } & \multicolumn{3}{|c|}{ Down C2C12 24h + SB } & \multicolumn{3}{|c|}{ Down $\mathrm{C} 2 \mathrm{C} 1248 \mathrm{~h}+\mathrm{SB}$} \\
\hline Factor & Genes & p-value & Factor & Genes & p-value & Factor & Genes & p-value \\
\hline Ap4 (3) & 231 & $4.38 \mathrm{E}-98$ & $\overline{\mathrm{Tcf} 3}$ & 147 & $7.9 \mathrm{E}-45$ & Ap4 (2) & 58 & $1.1 \mathrm{E}-24$ \\
\hline Tcf3 (E12) (2) & 276 & $1.44 \mathrm{E}-85$ & Maz:Myc & 130 & $7.2 \mathrm{E}-38$ & Sp1 & 76 & 5.4E-22 \\
\hline Foxo4 & 216 & 1.67E-61 & Sp1 & 149 & 1.3E-37 & Nfatc & 58 & 4.2E-20 \\
\hline Sp1 & 262 & 7.34E-61 & Nfatc & 108 & 3.6E-31 & Maz:Myc & 62 & $5.2 E-19$ \\
\hline Mef2 (6) & 124 & $6.84 \mathrm{E}-60$ & Ap1 (3) & 80 & $1.8 \mathrm{E}-29$ & Lef1 (2) & 57 & $1.2 \mathrm{E}-18$ \\
\hline Maz:Myc & 220 & $1.34 \mathrm{E}-56$ & Ap4 (2) & 93 & 4.9E-29 & Tcf3 & 63 & $9 E-18$ \\
\hline Myod (3) & 137 & $3.61 \mathrm{E}-56$ & Foxo4 & 103 & $3.1 \mathrm{E}-25$ & Pax4 & 45 & $9.1 \mathrm{E}-18$ \\
\hline Lef1 (2) & 196 & 5.56E-52 & Pax4 & 79 & $1 \mathrm{E}-24$ & Srf & 20 & 4.7E-16 \\
\hline Nfatc & 184 & 3.32E-47 & Lef1 (2) & 96 & $1 \mathrm{E}-22$ & Ap1 & 39 & 1.6E-15 \\
\hline Meis1 & 113 & $8.85 E-43$ & Ets2 & 67 & 2.4E-21 & Mef2 (2) & 29 & 4.5E-12 \\
\hline Pax4 & 138 & $9.93 \mathrm{E}-40$ & Myod & 58 & $6.2 \mathrm{E}-19$ & Tead1 & 22 & $6.2 \mathrm{E}-12$ \\
\hline $\mathrm{Nf1}$ & 99 & $1.11 \mathrm{E}-37$ & Meis1 & 50 & $7.9 \mathrm{E}-16$ & Tcf8 & 28 & 4.5E-10 \\
\hline Ap1 & 113 & $2.13 E-30$ & Mef2a & 45 & $2.2 \mathrm{E}-15$ & Evi1 & 15 & 3.9E-10 \\
\hline Vsx1 & 92 & $1.05 \mathrm{E}-28$ & Foxf2 & 48 & $6.7 \mathrm{E}-13$ & Foxo4 & 43 & $1.1 \mathrm{E}-09$ \\
\hline Tead1 & 58 & $4.87 \mathrm{E}-25$ & Tcf8 & 44 & $8 \mathrm{E}-13$ & Foxf2 & 27 & $1.8 \mathrm{E}-09$ \\
\hline Myc & 97 & $6.1 \mathrm{E}-24$ & Myc & 51 & $9.9 \mathrm{E}-13$ & Ets2 & 29 & 3.6E-09 \\
\hline Tcf8 & 47 & 8.74E-24 & Sif & 24 & 1.1E-12 & Nf1 & 23 & 6.6E-09 \\
\hline Tbp & 43 & $3.19 \mathrm{E}-21$ & Atf1 & 23 & $3.1 \mathrm{E}-12$ & Ap4 & 13 & $1.8 \mathrm{E}-08$ \\
\hline Ap4 & 42 & 1.1E-19 & $\mathrm{Nf1}$ & 40 & $9.8 \mathrm{E}-12$ & Meis1 & 24 & $1.8 \mathrm{E}-08$ \\
\hline Srf & 38 & 1.33E-18 & Err1 & 49 & $1.7 \mathrm{E}-11$ & Myod & 25 & 3.6E-08 \\
\hline
\end{tabular}

Fig. 3 Table showing transcription factor binding sites of p38a-regulated genes. Analyses of DNA-binding elements present in promoters were performed using GSEA. Red numbers indicate number of times that the factor appeared in the analysis with different DNA-binding elements, the highest $P$ value element is shown. Unknown binding elements have been omitted

organization, and serine/threonine and protein kinaserelated genes; genes bound only in proliferative conditions were enriched in Golgi apparatus genes, positive regulators of transcription and further enriched in Wnt signaling molecules. Interestingly, genes bound only in differentiating conditions were enriched in glycoproteins and membrane proteins, and in general, but negative regulators of transcription (positive general transcriptional regulators were not enriched) (Fig. 4c). Moreover, GSEA analysis of transcription factor binding sites in the p38 $\alpha$-bound genes identified enriched binding sites for nearly the same transcription factors found in p38 $\alpha$-regulated genes obtained in the expression microarrays, for example: Sp1, Lef1, Tcf3/E47, FoxO4, Pax4, MyoD, or Nfatc
(Fig. 4d). Since some of these transcription factors have been described as phosphorylation substrates of p38 MAPK in different model systems, including Sp1 [32, 33] Tcf3/E47 [12], NFATC4 [34], or E2F4 [35], and the pattern of $\mathrm{p} 38 \alpha$ recruitment to genes is mostly restricted to proximal promoter regions, it is tempting to propose that $\mathrm{p} 38 \alpha$ will likely regulate the myoblast proliferation-to-differentiation transition mainly through these transcription factors.

Of note, genome-wide binding analysis of $\mathrm{p} 38 \alpha$ in experimental conditions of myogenic differentiation, where p38 $\alpha$ is expressed but its kinase activity is inhibited (C2C12 cells in $\mathrm{DM}+\mathrm{SB}$ ), revealed that the kinase activity was not required for $\mathrm{p} 38 \alpha$ recruitment to chromatin; on the contrary, at the genome level, there was a generally increased occupancy 


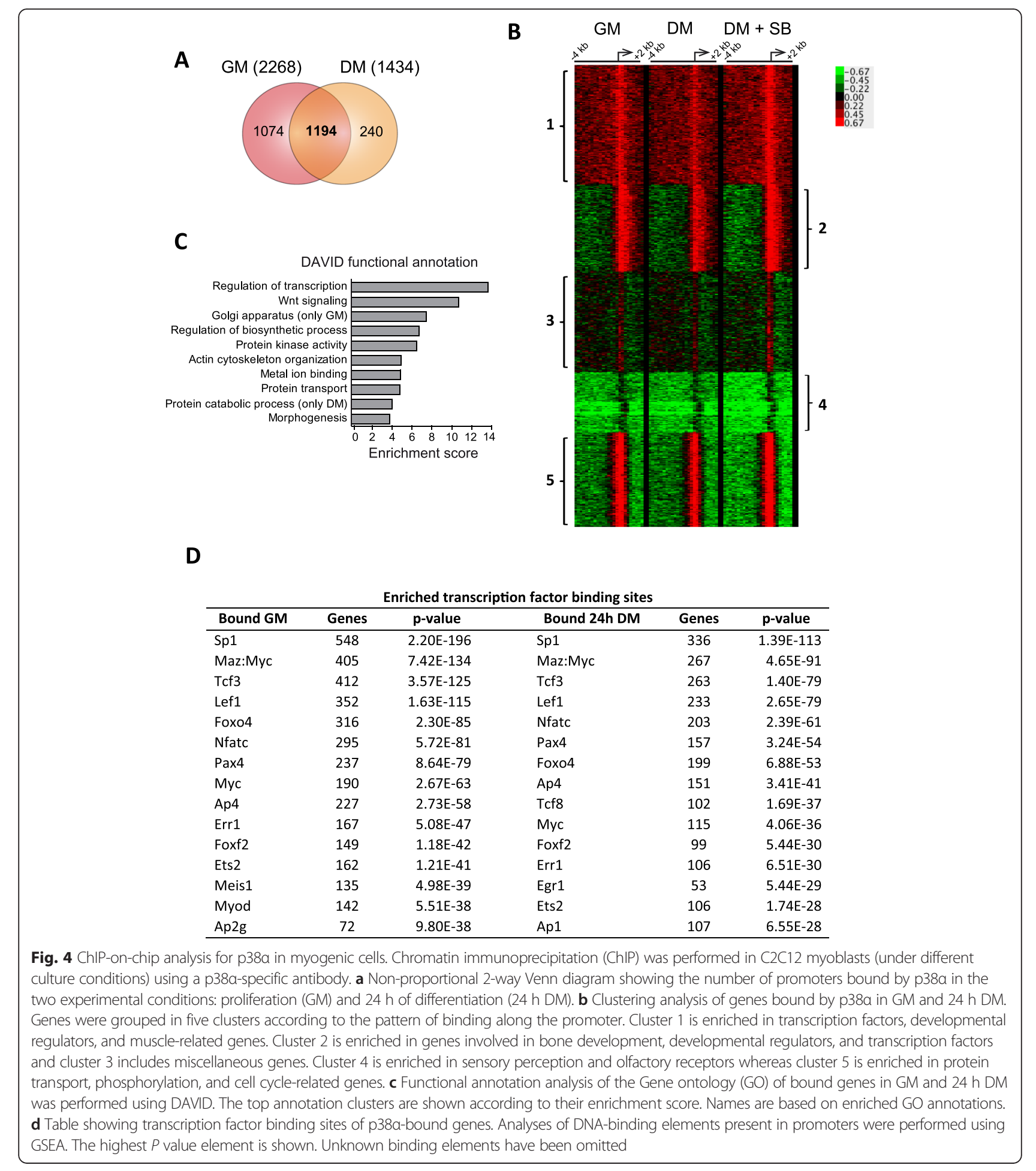

signal on promoters when cells were treated with the $p 38 \alpha / \beta$ inhibitor, as exemplified by full chromosome 11 and the promoter of Wnt9a, one of the p38 $\alpha$-regulated genes (Fig. 5). This indicates that recruitment of $\mathrm{p} 38 \alpha$ to certain gene promoters is independent of its kinase activity, although the underlying reason is currently unknown.

\section{Identification of genes bound and regulated by $\mathrm{p} 38 \mathrm{a}$ during early myogenic differentiation}

To complete the identification of the genes bound and regulated by $\mathrm{p} 38 \alpha$ at the myogenic proliferation-todifferentiation switch, we crossed the two data sets: the expression microarray and the ChIP-on-chip data. We 


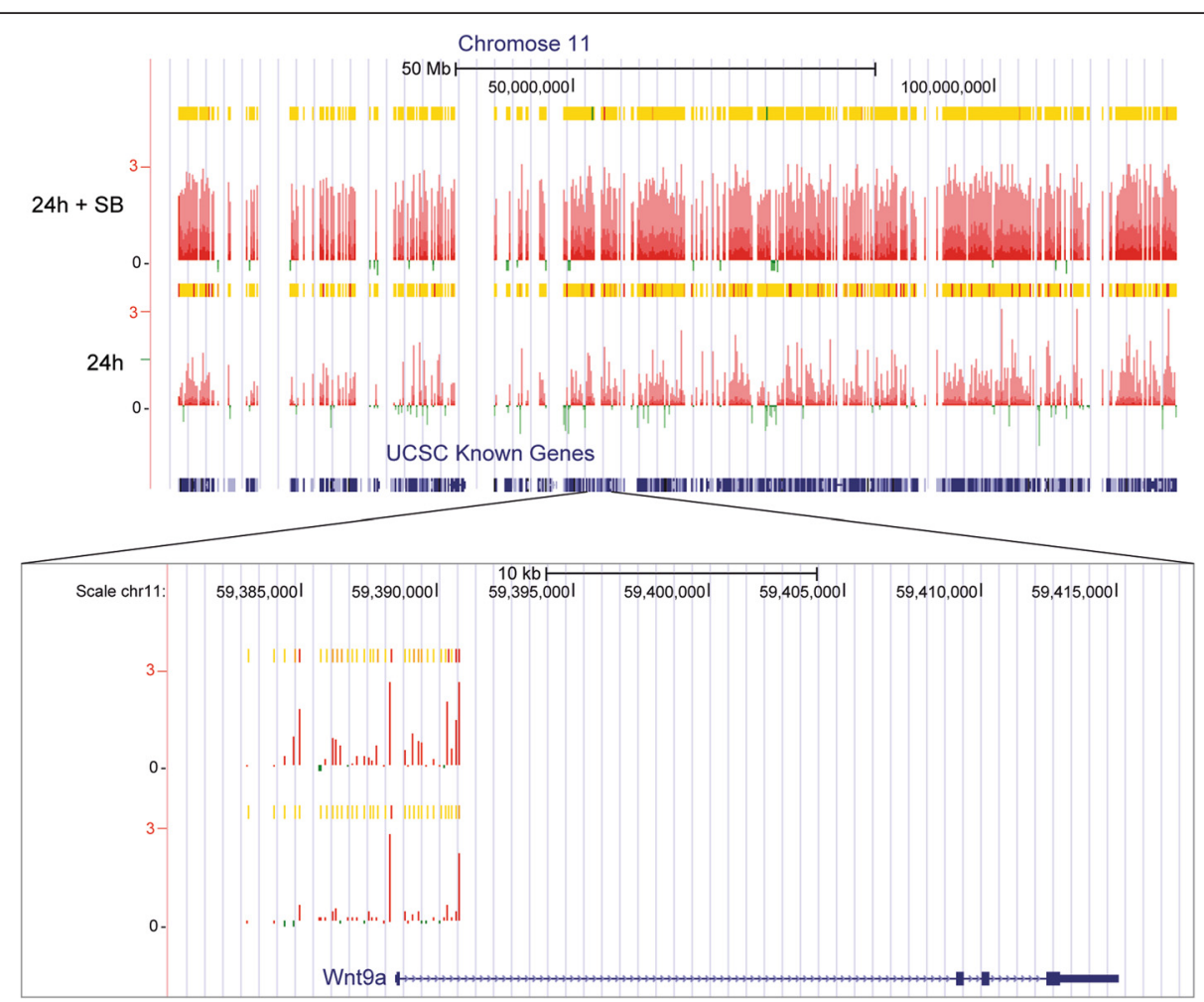

Fig. 5 The kinase activity is not required for p38a recruitment to chromatin. p38a-bound promoters in full chromosome 11 and the promoter of Wnt9a, one of the p38a-regulated genes, as an example of the general increased occupancy signal observed on promoters when cells were treated with the SB203580 p38a/ $\beta$ inhibitor. UCSC genome browser with overimposed binding signal is shown

identified 46 genes bound by $\mathrm{p} 38 \alpha$ that were upregulated in SB-treated $\mathrm{C} 2 \mathrm{C} 12$ myoblasts, and 70 genes bound and downregulated in similar $\mathrm{C} 2 \mathrm{C} 12$ cell culture conditions. Of these, only 10 and 12 genes were also up- and downregulated, respectively, in $\mathrm{p} 38 \alpha$-deficient satellite cells (Fig. 6a, b). Furthermore, GO analysis of the genes bound and regulated by $\mathrm{p} 38 \alpha$ in differentiating $\mathrm{C} 2 \mathrm{C} 12$ cells showed that they are mainly involved in signal transduction pathways, response to hypoxia, homeostatic processes, and cell proliferation. On the other hand, $\mathrm{GO}$ analysis of genes bound by $\mathrm{p} 38 \alpha$ and upregulated when $\mathrm{p} 38 \alpha$ activity was chemically inhibited showed enrichment for transcription factors and nuclear receptor coactivators (Fig. 6c). Interestingly, DAVID analysis of canonical pathways enriched in genes bound by $\mathrm{p} 38 \alpha$ highlighted the Wnt signaling pathway as the main signaling module regulated by p38 $\alpha$ (Fig. $6 \mathrm{~d}$ ).

We validated $\mathrm{p} 38 \alpha$ binding to the promoters of genes up- or downregulated after p38 inactivation in myogenic cells belonging to the different GO categories and pathways described above: Wnt signaling pathway (Wnt9a), actin cytoskeleton organization (Dock1), cellular signaling (RhoU, Kitl and Skil), and regulation of transcription (Spry1). This validation was performed through ChIP of cells cultured in three different conditions (GM, 24, and
$48 \mathrm{~h} \mathrm{DM}$-this latter time-point was included to extend the kinetics of $\mathrm{p} 38 \alpha$ binding), and subsequent semiquantitative or qPCR analysis of the immunopurified DNA (Fig. 7a, b). Moreover, and consistent with previously published results $[15,21]$, we found that $\mathrm{p} 38 \alpha$ recruitment to Myog and Pax7 promoters is increased upon differentiation (Fig. 7c). Of note, actual recruitment of the muscle regulatory factor MyoD (but not Mef2) to the newly identified p38 $\alpha$ targets Wnt9a and RhoU in differentiating $\mathrm{C} 2 \mathrm{C} 12$ myoblasts was confirmed by ChIP-qPCR (Fig. 7d, e).

\section{Discussion}

During myogenesis, satellite cells need to cease proliferation and initiate differentiation as a key step to fuse and form multinucleated myotubes. In vivo, this is the central step for the success of the tissue regeneration process in response to injury (i.e., forming new myofibers to repair the damaged muscle tissue). Previous studies had shown that the proliferation-to-differentiation transition of myoblasts (derived from satellite cells or from immortalized myogenic cell lines) requires timely activation of p38 $\alpha$ MAPK (reviewed in $[3,4,7,9]$ ), being this isoform also needed for proper muscle regeneration in mice [25]. Interestingly, this isoform was also shown to play an important role in muscular dystrophy progression 
A

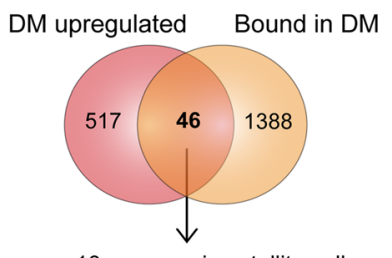

C

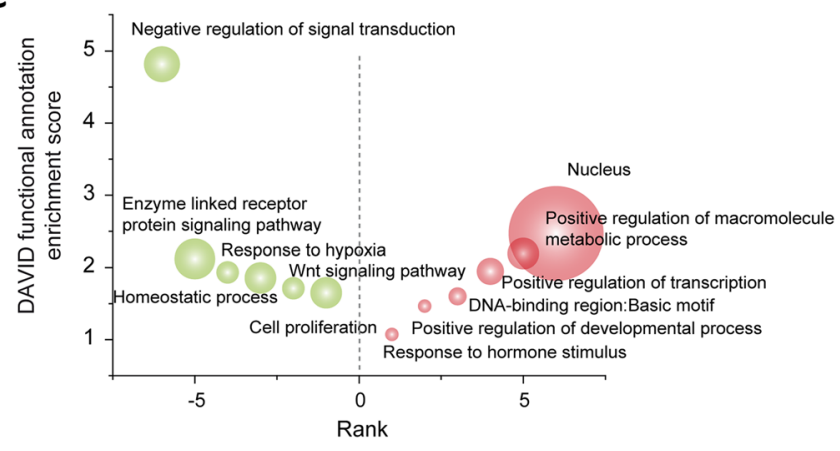

D

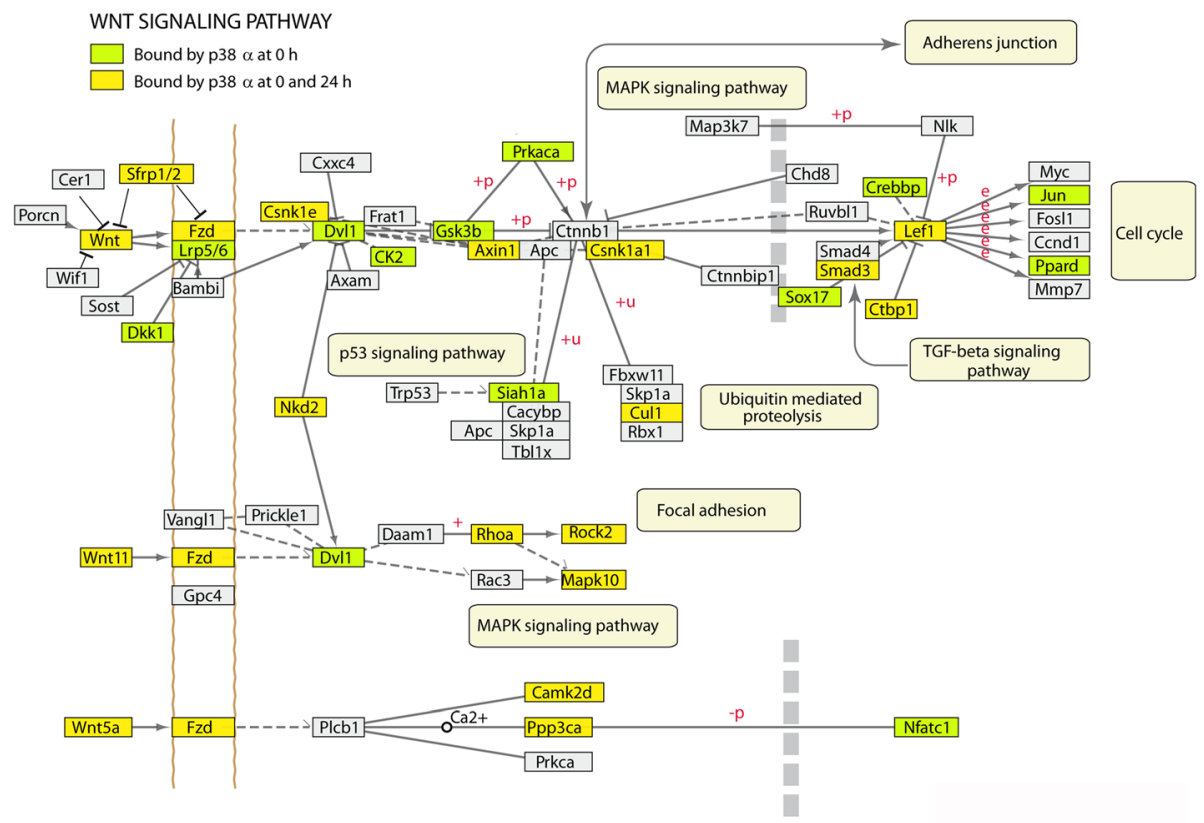

Fig. 6 Identification of genes bound and regulated by p38a. a, b The two data sets (expression array and ChIP-on-chip) were crossed to identify genes bound and regulated by p38a. The non-proportional 2-way Venn diagrams show that, at $24 \mathrm{~h}$ of differentiation (DM), p38a binds to the promoter of 46 genes upregulated in SB-treated C2C12 cells (a) and to 70 genes downregulated in myoblasts lacking active p38a (b). Only 10 and 12 of these bound genes are also upregulated and downregulated, respectively, in p38a-deficient satellite cells. c Gene ontology analysis of genes bound and regulated by p38a in C2C12 cells at $24 \mathrm{~h}$ in DM. Enriched GO annotations of genes downregulated in SB-treated C2C12 myoblasts are shown in green whereas enriched GO annotations of upregulated genes are shown in red. $\mathbf{d}$ DAVID analysis of canonical pathways enriched in genes bound by p38a showed that Wnt signaling pathway was one of the main signaling modules regulated by p38a. KEGG pathway is shown with p38a-bound promoters highlighted

in mice [36]. Here, we show that p38 $\alpha$ exerts this myogenic function at least in part via binding and acting at chromatin. By genome-wide localization analysis coupled to gene expression profiling, we found this p38 isoform associated with mammalian loci more frequently than in any study previously published. In particular, p38 $\alpha$ associated with chromatin during the myoblast proliferation-todifferentiation transition, and this correlated with the high 


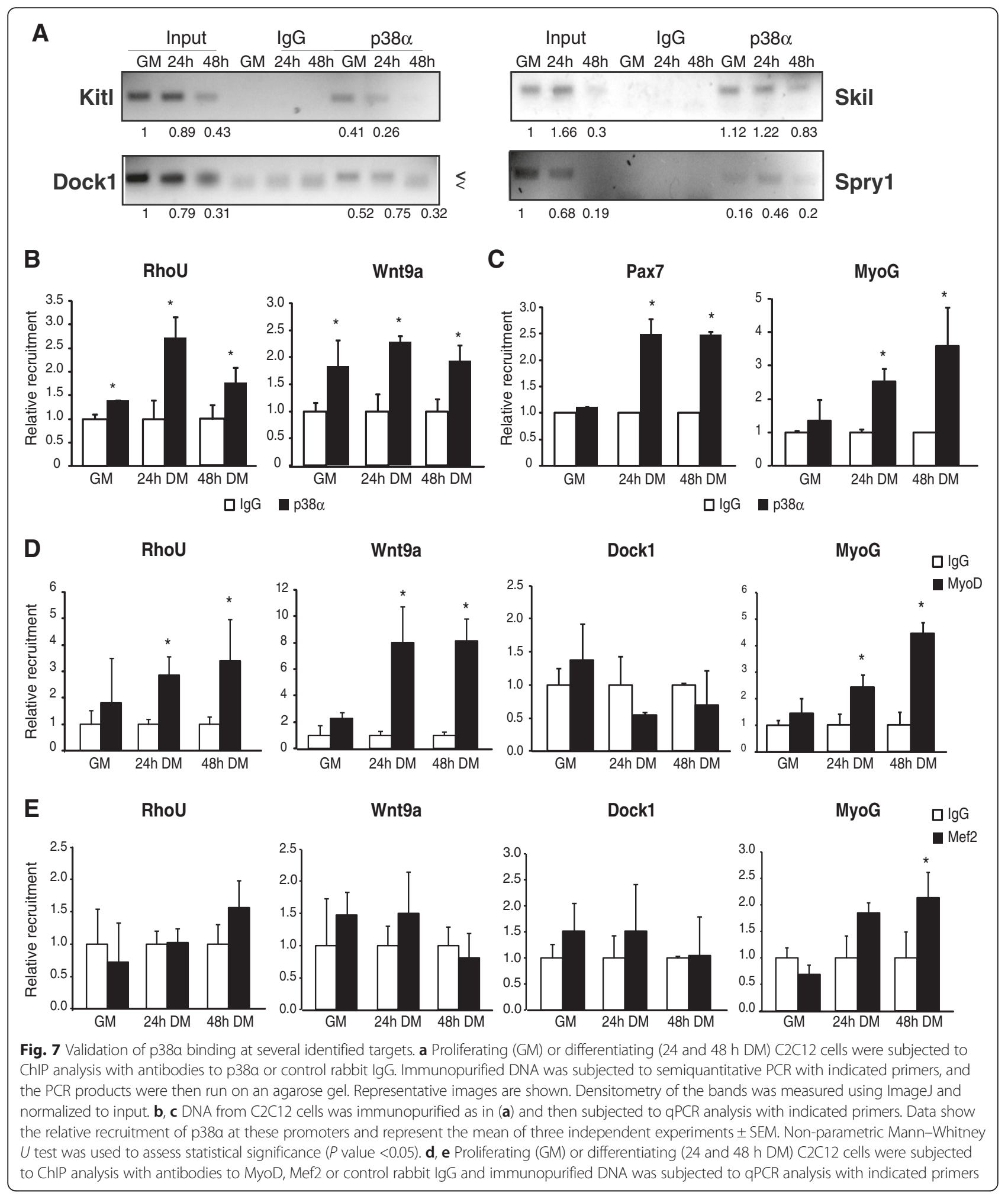

levels of transcription, supporting the relevance of kinase signaling pathways in directly regulating transcription, in agreement with previous reports [37-40]. At variance with the classical view of $\mathrm{p} 38 \alpha$ as a positive regulator of transcription [12, 41], we also found that the p38 $\alpha$ - chromatin binding was not always associated with active transcription during this myogenic transition, since many $\mathrm{p} 38 \alpha$-bound promoters were transcriptionally inactive or repressed. Thus, $\mathrm{p} 38 \alpha$ is recruited to a large set of myogenic gene promoters to facilitate their activation 
or repression, hence pointing to more complex regulatory mechanisms than previously anticipated.

How is $\mathrm{p} 38 \alpha$ recruited to muscle loci is not known, but it likely involves interaction with chromatinregulatory and/or transcription factors, as demonstrated for several stress-induced genes [42]. Of interest, p38 $\alpha$ bound promoters are enriched with binding motifs for several transcription factors, principally Sp1, Tcf3/E47, Lef1, FoxO4, MyoD, and NFATc, which are known to be phosphorylation substrates of p38 MAPK. In skeletal myoblasts, in particular, $\mathrm{p} 38 \alpha$ associates with MyoD and E47 [12, 15] transcription factors, and specific phosphorylation of E47 promotes E47/MyoD dimerization, binding to muscle-specific loci and initiation of gene expression [12]. Likewise, phosphorylation of MEF2 by p38 facilitates both recruitment of MyoD and expression of late myogenic genes, in a feed-forward mechanism [11], and of ASH2L-MLL methyltransferase complex $[18,19] . \mathrm{p} 38 \alpha$ also phosphorylates Baf60c allowing SWI/SNF-mediated chromatin remodeling at musclespecific loci [15-17]. Interestingly, p38 $\alpha$ was also shown to represses Pax7 gene expression via direct Ezh2 phosphorylation, as an indispensable event for the transition of proliferating myoblasts into their differentiating state [21]. Thus, p38 $\alpha$ may help both silence proliferation-associated genes and activate differentiation-promoting genes at this transition, by directly targeting negative and positive epigenetic and/or transcriptional regulators. Because the p38 MAPK homolog Hog1 targets the RNA Pol II machinery and induces chromatin remodeling at stress-responsive loci in yeast [43], it is possible that p38 $\alpha$ regulates Pol IIdependent gene transcription in mammalian myogenesis in a similar way. It is worth noting that $\mathrm{p} 38$ was also found on a subset of genes independently of its kinase activity. Our work adds to several recent studies of protein kinases that bind and act on chromatin: extracellular signal-regulated kinase (ERK), cJun Nterminal kinase (JNK), the MSK, AMPK, and Dyrk1A [37, 38, 44-46]. This study also complements the previously described association of $\mathrm{p} 38 / \operatorname{Hog} 1$ to osmostress genes to mediate adaptation to extracellular changes in mammals and yeast $[26,27,42]$.

Of interest, we observed slower muscle differentiation kinetics in $\mathrm{C} 2 \mathrm{C} 12$ myoblasts compared to satellite cells in culture; although the underlying causes for this difference are not clear, they may relate to the distinct nature of both cell types (freshly isolated cells versus immortalized cells) and the different velocity of $\mathrm{p} 38 \alpha$ activation in both cell types (see Fig. 1a). Whether the expression of the identified p38 $\alpha$-regulated late genes depends on the early ones, according to the proposed temporal regulation of muscle gene expression through a MyoDmediated feed-forward circuit involving p38 MAPK [11], is not yet known.
Finally, although the nature of p38 $\alpha$-regulated genes encompasses several categories, DAVID analysis of canonical pathways enriched in genes bound by p38 $\alpha$ showed the Wnt pathway as the main signaling module regulated by $\mathrm{p} 38 \alpha$. Consistent with this, MyoD was found to be recruited to the newly identified p38 $\alpha$ target Wnt9a, in addition to muscle-specific gene promoters, as expected. This is worth highlighting based on the reported relevant role of canonical and non-canonical Wnt signaling in distinct satellite cell functions in vivo (expansion, switching from proliferation to differentiation or cell motility) [47-49]. Taken together, this study increases our understanding on how p38 MAPK regulates gene expression during myogenesis, and greatly enlarges the number and nature of target genes downstream of $\mathrm{p} 38 \alpha$ activation. Notably, through this analysis, we have become aware of new categories of genes whose repression depends on p38 $\alpha$ both in proliferating and differentiating conditions, expanding, yet complicating, the function of $\mathrm{p} 38 \alpha$ as a negative regulator of muscle gene transcription. It is possible that comparable principles of chromatin binding and activity might be relevant for other kinases.

\section{Conclusions}

Collectively, through this study, we demonstrate association and action of p38 $\alpha$ MAPK throughout chromatin uncovering new classes of target genes during the transition of myoblasts from proliferation to differentiation. The recruitment of $\mathrm{p} 38 \alpha$ to large sets of gene promoters appears to facilitate their activation or repression during this process. This is consistent with this MAPK isoform being a transcriptional regulator.

\section{Additional files}

Additional file 1: Table S2. List of primers used in the study. (XLSX $12 \mathrm{~kb}$ )

Additional file 2: Table S1. List of genes regulated and bound by p38a. (XLSX 686 kb)

Additional file 3: Supplementary Figures 1 and 2 and legends. Figure S1. Relative expression of p38a and $p 38 \beta$ in C2C12 cells. The expression of $p 38 a$ and $p 38 \beta$ was measured by $q P C R$ in differentiating C2C12 cells. Values are mean \pm SEM of three independent set of samples. Figure S2. Nuclear p38a remains constant in proliferating and differentiating myoblasts. Expression of p38a in C2C12 cells in GM and $24 \mathrm{~h}$ in DM: p38a (green) and DAPI (blue). Nuclear to cytoplasm fluorescence ratio was calculated using integrated density values in ImageJ software with DAPI as nuclear boundary. Scale bar $=25 \mu \mathrm{m}$. (PDF $7595 \mathrm{~kb}$ )

\section{Abbreviations}

BAF60c: BRG1/BRM-associated factor 60 variant c; ChIP: chromatin immunoprecipitation; DAPI: 4',6-diamidino-2-phenylindole;

DM: differentiation medium; Dock1: dedicator of cytokinesis; FoxO4: forkhead box protein O4; GM: growth medium; GO: gene ontology; GSEA: gene set enrichment analysis; Lef1: lymphoid enhancer-binding factor 1;

MAPK: mitogen-activated protein kinase; MEF2: myocyte enhancer factor 2; MRFs: myogenic regulatory factors; NFATc: nuclear factor of activated T cells; Pax4: paired box gene 4; RT-qPCR: reverse transcriptase quantitative 
polymerase chain reaction; Spry1: protein sprouty homolog 1; Tcf3: transcription factor 3 (E2A immunoglobulin enhancer-binding factors E12/E47); Wnt9a: wingless-type MMTV integration site family, member 9A; WT: wild type.

\section{Competing interests}

The authors declared that they have no competing interests.

\section{Authors' contributions}

JS designed and performed experiments, analyzed data, and interpreted results and wrote the manuscript. ABMMK performed bioinformatic analysis and edited the manuscript. RK performed bioinformatic analysis and edited the manuscript. QL performed experiments. PS-V performed experiments. FJD performed experiments, analyzed data, and interpreted results. EB performed ChIP experiments and edited the manuscript. EP designed and performed experiments, analyzed data, and interpreted results and wrote the manuscript. PMC conceived the project, designed experiments, interpreted results, and wrote the manuscript. All authors read and approved the final manuscript.

\section{Acknowledgements}

We thank Drs. V. Ruiz-Bonilla, M. Jardí, and M. Raya, for their help and contribution to this study. The CRG/UPF Genomic Unit for excellent support. The authors acknowledge funding from MINECO, Spain (SAF2012-38547, PLE2009-0124, SAF2015-67369-R, "María de Maeztu" Programme for Units of Excellence in R\&D MDM-2014-0370), AFM, MDA, DDPNetherlands, E-RARE, Fundació Marató TV3 and EU-FP7 (Myoage, Optistem and Endostem). JS is recipient of a Juan de la Cierva postdoctoral fellowship.

\section{Author details}

'Department of Experimental and Health Sciences, Pompeu Fabra University (UPF), CIBER on Neurodegenerative diseases (CIBERNED), Barcelona, Spain. ${ }^{2}$ Department of Genetic Engineering and Biotechnology, University of Dhaka, Dhaka 1000, Bangladesh. ${ }^{3}$ Wyss Institute for Biologically Inspired Engineering, Harvard University, Boston, MA 02115, USA. ${ }^{4}$ Sprott Center for Stem Cell Research, Ottawa Hospital Research Institute, Ottawa, ON K1H 8L6, Canada. ${ }^{5}$ Chromatin and Disease Group, Cancer Epigenetics and Biology Programme (PEBC), Bellvitge Biomedical Research Institute (IDIBELL), Barcelona, Spain. ${ }^{6}$ Institució Catalana de Recerca i Estudis Avançats (ICREA), Barcelona, Spain. ${ }^{7}$ Present address: Buck Institute for Research on Aging, Novato, CA, USA.

\section{Received: 11 September 2015 Accepted: 5 January 2016}

\section{Published online: 15 March 2016}

\section{References}

1. Cuenda A, Rousseau S. p38 MAP-kinases pathway regulation, function and role in human diseases. Biochim Biophys Acta. 2007;1773(8):1358-75. doi:10.1016/j.bbamcr.2007.03.010.

2. Cuadrado A, Nebreda AR. Mechanisms and functions of p38 MAPK signalling. Biochem J. 2010;429(3):403-17. doi:10.1042/BJ20100323.

3. Lluis F, Perdiguero E, Nebreda AR, Munoz-Canoves P. Regulation of skeletal muscle gene expression by p38 MAP kinases. Trends Cell Biol. 2006;16(1):36-44. doi:10.1016/j.tcb.2005.11.002.

4. Keren A, Tamir Y, Bengal E. The p38 MAPK signaling pathway: a major regulator of skeletal muscle development. Mol Cell Endocrinol. 2006;252(1-2):224-30. doi:10.1016/j.mce.2006.03.017.

5. Mahmoudi S, Brunet A. Aging and reprogramming: a two-way street. Curr Opin Cell Biol. 2012;24(6):744-56. doi:10.1016/j.ceb.2012.10.004.

6. Neves J, Demaria M, Campisi J, Jasper H. Of flies, mice, and men: evolutionarily conserved tissue damage responses and aging. Dev Cell. 2015;32(1):9-18. doi:10.1016/j.devcel.2014.11.028.

7. Perdiguero E, Ruiz-Bonilla V, Gresh L, Hui L, Ballestar E, Sousa-Victor P, et al. Genetic analysis of p38 MAP kinases in myogenesis: fundamental role of p38alpha in abrogating myoblast proliferation. EMBO J. 2007;26(5):1245-56.

8. Mourikis $\mathrm{P}$, Tajbakhsh S. Distinct contextual roles for Notch signalling in skeletal muscle stem cells. BMC Dev Biol. 2014;14:2. doi:10.1186/1471-213X-14-2.

9. Vahidi Ferdousi L, Rocheteau P, Chayot R, Montagne B, Chaker Z, Flamant P, et al. More efficient repair of DNA double-strand breaks in skeletal muscle stem cells compared to their committed progeny. Stem Cell Res. 2014;13(3 Pt A):492-507. doi:10.1016/j.scr.2014.08.005.
10. Zhao M, New L, Kravchenko W, Kato Y, Gram H, Di Padova F, et al. Regulation of the MEF2 family of transcription factors by p38. Mol Cell Biol. 1999;19(1):21-30

11. Penn BH, Bergstrom DA, Dilworth FJ, Bengal E, Tapscott SJ. A MyoDgenerated feed-forward circuit temporally patterns gene expression during skeletal muscle differentiation. Genes Dev. 2004;18(19):2348-53.

12. Lluis F, Ballestar E, Suelves M, Esteller M, Munoz-Canoves P. E47 phosphorylation by p38 MAPK promotes MyoD/E47 association and muscle-specific gene transcription. EMBO J. 2005;24(5):974-84. doi:10.1038/sj.emboj.7600528.

13. Perdiguero E, Sousa-Victor P, Ballestar E, Munoz-Canoves P. Epigenetic regulation of myogenesis. Epigenetics. 2009;4(8):541-50.

14. Fulle S, Di Donna S, Puglielli C, Pietrangelo T, Beccafico S, Bellomo R, et al. Age-dependent imbalance of the antioxidative system in human satellite cells. Exp Gerontol. 2005;40(3):189-97. doi:10.1016/j.exger.2004. 11.006.

15. Simone C, Forcales SV, Hill DA, Imbalzano AN, Latella L, Puri PL. p38 pathway targets SWI-SNF chromatin-remodeling complex to muscle-specific loci. Nat Genet. 2004;36(7):738-43. doi:10.1038/ng1378ng1378.

16. Serra C, Palacios D, Mozzetta C, Forcales SV, Morantte I, Ripani M, et al. Functional interdependence at the chromatin level between the MKK6/p38 and IGF1/PI3K/AKT pathways during muscle differentiation. Mol Cell. 2007;28(2):200-13. doi:10.1016/j.molcel.2007.08.021.

17. Forcales SV, Albini S, Giordani L, Malecova B, Cignolo L, Chernov A, et al. Signal-dependent incorporation of MyoD-BAF60C into Brg1-based SWI/SNF chromatin-remodelling complex. EMBO J. 2012;31(2):301-16. doi:10.1038/emboj.2011.391.

18. Rampalli S, Li L, Mak E, Ge K, Brand M, Tapscott SJ, et al. p38 MAPK signaling regulates recruitment of Ash2L-containing methyltransferase complexes to specific genes during differentiation. Nat Struct Mol Biol. 2007;14(12):1150-6. doi:10.1038/nsmb1316.

19. Brack AS, Bildsoe H, Hughes SM. Evidence that satellite cell decrement contributes to preferential decline in nuclear number from large fibres during murine age-related muscle atrophy. J Cell Sci. 2005;118(Pt 20):4813-21. doi:10.1242/jcs.02602.

20. Cuadrado A, Corrado N, Perdiquero E, Lafarga V, Munoz-Canoves P, Nebreda AR. Essential role of p18(Hamlet)/SRCAP-mediated histone H2A.Z chromatin incorporation in muscle differentiation. EMBO J. 2010. doi:10.1038/emboj.2010.85.

21. Palacios D, Mozzetta C, Consalvi S, Caretti G, Saccone V, Proserpio V, et al. TNF/p38alpha/polycomb signaling to Pax7 locus in satellite cells links inflammation to the epigenetic control of muscle regeneration. Cell Stem Cell. 2010;7(4):455-69. doi:10.1016/j.stem.2010.08.013.

22. Gillespie MA, Le Grand F, Scime A, Kuang S, von Maltzahn J, Seale V, et al. p38-\{gamma\}-dependent gene silencing restricts entry into the myogenic differentiation program. J Cell Biol. 2009;187(7):991-1005. doi:10.1083/jcb.200907037.

23. Ruiz-Bonilla V, Perdiguero E, Gresh L, Serrano AL, Zamora M, Sousa-Victor P, et al. Efficient adult skeletal muscle regeneration in mice deficient in p38beta, p38gamma and p38delta MAP kinases. Cell Cycle. 2008;7(14):2208-14.

24. Wang $H, X u$ Q, Xiao F, Jiang Y, Wu Z. Involvement of the p38 mitogen-activated protein kinase alpha, beta, and gamma isoforms in myogenic differentiation. Mol Biol Cell. 2008;19(4):1519-28. doi:10.1091/mbc.E07-08-0817.

25. Brien P, Pugazhendhi D, Woodhouse S, Oxley D, Pell JM. p38alpha MAPK regulates adult muscle stem cell fate by restricting progenitor proliferation during postnatal growth and repair. Stem Cells. 2013;31(8):1597-610. doi:10.1002/stem.1399.

26. De Nadal E, Zapater M, Alepuz PM, Sumoy L, Mas G, Posas F. The MAPK Hog1 recruits Rpd3 histone deacetylase to activate osmoresponsive genes. Nature. 2004;427(6972):370-4. doi:10.1038/nature02258.

27. Pokholok DK, Zeitlinger J, Hannett NM, Reynolds DB, Young RA. Activated signal transduction kinases frequently occupy target genes. Science. 2006;31(5786):533-6. doi:10.1126/science.1127677.

28. Ferreiro I, Barragan M, Gubern A, Ballestar E, Joaquin M, Posas F. The p38 SAPK is recruited to chromatin via its interaction with transcription factors. J Biol Chem. 2010;285(41):31819-28. doi:10.1074/jbc.M110.155846.

29. Gentleman RC, Carey VJ, Bates DM, Bolstad B, Dettling M, Dudoit S, et al. Bioconductor: open software development for computational biology and bioinformatics. Genome Biol. 2004;5(10):R80. doi:10.1186/gb-2004-5-10-r80.

30. da Huang W, Sherman BT, Lempicki RA. Systematic and integrative analysis of large gene lists using DAVID bioinformatics resources. Nat Protoc. 2009;4(1):44-57. doi:10.1038/nprot.2008.211. 
31. Subramanian A, Tamayo P, Mootha VK, Mukherjee S, Ebert BL, Gillette MA, et al. Gene set enrichment analysis: a knowledge-based approach for interpreting genome-wide expression profiles. Proc Natl Acad Sci U S A. 2005;102(43):15545-50. doi:10.1073/pnas.0506580102.

32. D'Addario M, Arora PD, McCulloch CA. Role of $\mathrm{p} 38$ in stress activation of Sp1. Gene. 2006:379:51-61. doi:10.1016/.jgene.2006.04.012.

33. Xu K, Shu HK. EGFR activation results in enhanced cyclooxygenase-2 expression through p38 mitogen-activated protein kinase-dependent activation of the Sp1/Sp3 transcription factors in human gliomas. Cancer Res. 2007;67(13):6121-9. doi:10.1158/0008-5472.CAN-07-0141.

34. Yang TT, Xiong Q, Enslen H, Davis RJ, Chow CW. Phosphorylation of NFATc4 by p38 mitogen-activated protein kinases. Mol Cell Biol. 2002;22(11):3892-904.

35. Morillo SM, Abanto EP, Roman MJ, Frade JM. Nerve growth factorinduced cell cycle reentry in newborn neurons is triggered by p38MAPK-dependent E2F4 phosphorylation. Mol Cell Biol. 2012;32(14):2722-37. doi:10.1128/MCB.00239-12.

36. Wissing ER, Boyer JG, Kwong JQ, Sargent MA, Karch J, McNally EM, et al. P38alpha MAPK underlies muscular dystrophy and myofiber death through a Bax-dependent mechanism. Hum Mol Genet. 2014;23(20):5452-63. doi:10.1093/hmg/ddu270.

37. Tiwari VK, Stadler MB, Wirbelauer C, Paro R, Schubeler D, Beisel C. A chromatin-modifying function of JNK during stem cell differentiation. Nat Genet. 2011;44(1):94-100. doi:10.1038/ng.1036.

38. Vicent GP, Ballare C, Nacht AS, Clausell J, Subtil-Rodriquez A, Quiles I, et al. Induction of progesterone target genes requires activation of Erk and Msk kinases and phosphorylation of histone H3. Mol Cell. 2006;24(3):367-81. doi:10.1016/j.molcel.2006.10.011.

39. Bungard D, Fuerth BJ, Zeng PY, Faubert B, Maas NL, Viollet B, et al. Signaling kinase AMPK activates stress-promoted transcription via histone $\mathrm{H} 2 \mathrm{~B}$ phosphorylation. Science. 2010;329(5996):1201-5. doi:10.1126/science.1191241.

40. Di Vona C, Bezdan D, Islam AB, Salichs E, Lopez-Bigas N, Ossowski S, et al. Chromatin-wide profiling of DYRK1A reveals a role as a genespecific RNA polymerase II CTD kinase. Mol Cell. 2015;57(3):506-20. doi:10.1016/j.molcel.2014.12.026.

41. Putker M, Madl T, Vos HR, de Ruiter H, Visscher M, van den Berg MC, et al. Redox-dependent control of FOXO/DAF-16 by transportin-1. Mol Cell. 2013:49(4):730-42. doi:10.1016/.molcel.2012.12.014.

42. Rezza A, Sennett R, Rendl M. Adult stem cell niches: cellular and molecular components. Curr Top Dev Biol. 2014;107:333-72. doi:10.1016/B978-0-12-416022-4.00012-3.

43. Nadal-Ribelles M, Conde N, Flores O, Gonzalez-Vallinas J, Eyras E, Orozco M, et al. Hog1 bypasses stress-mediated down-regulation of transcription by RNA polymerase II redistribution and chromatin remodeling. Genome Biol. 2012;13(11):R106. doi:10.1186/gb-2012-13-11-r106.

44. Aurora $A B$, Olson EN. Immune modulation of stem cells and regeneration. Cell Stem Cell. 2014;15(1):14-25. doi:10.1016/j.stem.2014.06.009.

45. Murphy MM, Keefe AC, Lawson JA, Flygare SD, Yandell M, Kardon G. Transiently active Wnt/beta-catenin signaling is not required but must be silenced for stem cell function during muscle regeneration. Stem Cell Rep. 2014;3(3):475-88. doi:10.1016/.stemcr.2014.06.019.

46. Lawrence MC, McGlynn K, Shao C, Duan L, Naziruddin B, Levy MF, et al. Chromatin-bound mitogen-activated protein kinases transmit dynamic signals in transcription complexes in beta-cells. Proc Natl Acad Sci U S A. 2008;105(36):13315-20. doi:10.1073/pnas.0806465105.

47. Le Grand F, Jones AE, Seale V, Scime A, Rudnicki MA. Wnt7a activates the planar cell polarity pathway to drive the symmetric expansion of satellite stem cells. Cell Stem Cell. 2009;4(6):535-47. doi:10.1016/j.stem.2009.03.013.

48. Tanaka S, Terada K, Nohno T. Canonical Wnt signaling is involved in switching from cell proliferation to myogenic differentiation of mouse myoblast cells. J Mol Signal. 2011;6:12. doi:10.1186/1750-2187-6-12.

49. Bentzinger CF, von Maltzahn J, Dumont NA, Stark DA, Wang YX, Nhan $\mathrm{K}$, et al. Wnt7a stimulates myogenic stem cell motility and engraftment resulting in improved muscle strength. J Cell Biol. 2014;205(1):97-111. doi:10.1083/jcb.201310035

\section{Submit your next manuscript to BioMed Central and we will help you at every step:}

- We accept pre-submission inquiries

- Our selector tool helps you to find the most relevant journal

- We provide round the clock customer support

- Convenient online submission

- Thorough peer review

- Inclusion in PubMed and all major indexing services

- Maximum visibility for your research

Submit your manuscript at www.biomedcentral.com/submit 